\title{
Demographic consequences of within-year variation in recruitment
}

\author{
Catherine A. Pfister* \\ Department of Zoology, NJ-15, University of Washington, Seattle, Washington 98195, USA
}

\begin{abstract}
I explored the consequences of variance in the timing of recruitment to early growth and survivorship in a guild of sculpins that occupy intertidal areas on the outer coast of Washington state (USA). When I quantified the appearance of new recruits every month for $3 \mathrm{yr}$, I found seasonal peaks in recruitment for the 3 most common species in this system, although fishes recruited throughout the spring and summer months. Mark-recapture studies revealed especially strong seasonal growth patterns in 2 of the 3 species, with increased growth rates during the summer months. This effect was most pronounced for young-of-the-year fishes. As a consequence, individuals of all species reach reproductive size more rapidly and benefit from higher survivorship to reproductive size when they recruit earlier in the spring and summer. These demographic consequences of within-year recruitment variation appear driven by large-scale oceanographic events, since recruitment in all 3 species can be correlated with upwelling and/or sea surface temperature. Although these results suggest that within-season recruitment variation, via its effect on juvenile performance, may affect the population trajectories of these nearshore fishes, previous research in this system also indicates a strong role for adult survivorship patterns. Thus, understanding the net effect of pelagic events in driving population dynamics of organisms with complex life cycles requires integration of both pelagic and benthic life history events.
\end{abstract}

KEY WORDS: Cottidae - Intertidal fishes Upwelling Recruitment variation . Timing of recruitment Complex life cycles - Benthic-pelagic coupling Demographic variability

\section{INTRODUCTION}

The larval stage of marine organisms continues to represent a challenge to ecologists who seek to characterize the components of population growth of marine organisms and the processes that influence multi-species assemblages. Variability in the number of young that establish in a population, referred to here as recruitment, has the potential to determine abundance patterns for that organism for a long time in the future. For organisms whose adult stage inhabits nearshore areas, the completion of the larval planktonic stage and successful reestablishment on the shore is essential. In some organisms, especially in tropical reef environments, reproduction and thus recruitment may be a continuous process with only slight seasonality (Sale

\footnotetext{
- Present address: Dept of Ecology and Evolution, 1101 E. 57th St., University of Chicago, Chicago, Illinois 60637, USA

E-mail: cpfister@midway.uchicago.edu
}

1977, McFarland et al. 1985, Victor 1986). On the other hand, there is usually a strong seasonal component to recruitment in temperate and occasionally tropical areas (e.g. Victor 1983, Caffey 1985, Raimondi 1990, Morgan \& Christy 1995, Pfister 1996). In temperate areas, marine fishes and invertebrates typically recruit in pulses, usually in the spring and summer months. Although there may be well-defined peaks when the majority of individuals return to the adult population, there is often a period of months over which recruits establish (Loosanoff 1964, Yoshioka 1982, Caffey 1985, Gaines \& Roughgarden 1985, Raimondi 1990, Doherty 1991, Bingham 1992, Kneib 1993, Secor \& Houde 1995). This spread could be due to variation in the timing of spawning, variation in the duration in the plankton, differential survival during the planktonic stage, or any combination of these, and remains a major barrier to an integrated understanding of life histories which include planktonic and benthic phases. 
Variability in recruitment may reflect variability in oceanographic events such as upwelling and spring algal blooms, since the establishment of some marine organisms is often cued to predictable oceanographic or lunar events. For example, both the timing of spawning and the recruitment of marine organisms can occur in lunar cycles (e.g. Korringa 1947, Johannes 1978, Connell 1985, Babcock et al. 1986, Kneib 1986. Robertson et al. 1990, Morgan \& Christy 1995), and tidally forced internal waves have been associated with the return of relatively high densities of fish and invertebrate propagules to shore (Shanks 1983). Sissenwine (1984) summarized correlative studies between the recruitment of exploited temperate finfish stocks and a number of physical factors such as wind direction, air temperature, and the intensity of coastal upwelling; the recruitment success of commercially exploited species in the northeast Pacific was often positively correlated with indices of upwelling. Although upwelling events can supply necessary seasonal resources to larvae, they can also be associated with offshore Ekman transport, which may be detrimental to organisms which need to return to shore. For example, the recruitment success of barnacles on the central California, USA, shore was negatively correlated with an index of upwelling (Roughgarden et al 1988).

Despite an increasing number of studies documenting variability in larval supply and recruitment of marine organisms, we still know very little about whether temporal variation has a lasting and detectable effect on populations (but see Jones 1990, Doherty \& Fowler 1994, Pfister 1996). Whether intraannual variability in recruitment is important to individuals depends upon how differences in timing affect growth and survivorship. Perhaps it is easiest to understand how benefits would accrue to an individual that recruits earlier than others. Establishing earlier than competitors has been shown to favor individual fishes in intra- and interspecific encounters for shelter (Shulman 1985). In thermally stressful intertidal habitats in the Gulf of California, barnacles that recruited earlier and obtained better microsites had a higher survivorship than those that recruited later (Raimondi 1990). Priority effects may also benefit individuals who need to grow through a period of vulnerability to predators (Shulman et al. 1983). Additionally, in an area where prey resources may have been limited, larval mummichog fish that established earlier had a higher survivorship than those that were manipulated experimentally to establish later (Kneib 1993). In contrast, later season recruitment coincided with higher rates of survivorship and growth for a Hawaiian coral reef damselfish (Booth 1995), although these individuals were more vulnerable to predation in the subsequent season. These studies demonstrate how differences in the timing of early life history events can affect the future performance of individuals.

I explored whether variability in the timing of recruitment, correlated with large-scale oceanographic events, affects the performance of individuals during their first months as part of the benthic population. I used 3 yr of demographic information on 2155 marked individuals in a guild of tidepool fishes in tandem with automated buoy data to ask: (1) do large-scale oceanographic events correlate with the timing of fish recruitment? and (2) does variation in the timing of recruitment affect individual growth, survivorship, and the time interval to first reproduction? My analyses indicate that oceanographic effects on planktonic events have predictable consequences for early benthic life histories.

\section{STUDY SYSTEM}

The natural history of intertidal sculpins (Order Scorpaeniformes) has been described in detail elsewhere (Pfister 1993, 1995, 1996). Briefly, with the exception of a 1 to 2 mo larval period in the plankton (Washington et al. 1984), sculpins spend the majority of their life in intertidal habitats, including tidepools and surge channels. Intertidal sculpins recruit during the spring and summer months. As adults $>35 \mathrm{~mm}$ standard length., $\mathrm{SL})$, they seem to inhabit a restricted area of the shore; individuals are routinely caught in a single or small group of tidepools (Richkus 1973, Pfister 1995). Their homing capabilities facilitate this site fidelity (Green 1971, 1973, Yoshiyama et al. 1992, author's pers. obs.). As many as 6 to 8 species of primarily intertidal sculpins can be found at a variety of locales in the northeast Pacific and all appear to reproduce in late winter and early spring; recruitment occurs from spring to summer (Hart 1973, Pfister 1996). Little is known about the planktonic larval stage. Although there is one report that newly hatched larvae school close to the substrate (Marliave 1986) potentially remaining close to their parental source, many individuals live in extremely exposed, high energy habitats where tidal and wind-driven currents may result in long distance dispersal. The genetic data for intertidal sculpins (gel electrophoresis data; Waples 1987. Yoshiyama \& Sassaman 1987) provide little evidence for population substructure on scales of hundreds of kilometers in the northeast Pacific.

In the northeast Pacific, a predictable oceanographic event is the spring transition which initiates upwelling in March or April (Strub et al. 1987, Strub \& James 1988). Alongshore surface currents shift to become predominantly southward and upwelling persists through- 
out the summer. Sea surface temperature (SST, in ${ }^{\circ} \mathrm{C}$ ) also varies seasonally in the northeast Pacific and temperature has often been thought to be a correlate of recruitment (e.g. Grossman 1982). Thus, I focussed on upwelling and SST when looking for correlations among oceanographic events and variability in recruitment.

The recruitment data reported here are from Tatoosh Island, Washington, USA. Tatoosh Island $\left(48.40^{\circ} \mathrm{N}\right.$, $124.73^{\circ} \mathrm{W}$ ) is separated by a $0.6 \mathrm{~km}$ water gap from the northwest tip of the Olympic Peninsula. It is an exposed rocky intertidal site, encountering directly the predominantly westerly swells and winds. There are 3 species of intertidal sculpins routinely found on Tatoosh Island. Their rank abundance by biomass in mid intertidal pools is: Clinocottus globiceps, Oligocottus maculosus, and $C$. embryum. Information on biotic interactions between intertidal sculpins and spatial patterns in recruitment is presented elsewhere (Pfister 1995, 1996)

\section{METHODS}

Temporal recruitment patterns. I censused tidepool sculpins by draining a tidepool partially, mixing in a few drops of the anesthetic Quinaldine, and then dipnetting any fish that came swimming to the surface, while continually pouring water into crevices to flush out fishes. The fishes were transferred to a bucket with untainted seawater where they rapidly recovered from any ill effects of Quinaldine. I then drained the remaining water from the pool, thoroughly searched the pool again, and refilled the pool with seawater.

From September 1990 to September 1993 I quantified the number of sculpins that had recruited in the previous month by marking and recapturing sculpins at approximately 1 mo intervals in 9 tidepools. I marked fishes by injecting small dots of colored, acrylic paint (Ceramcoat, Delta Technical Coatings, Inc., Whittier, CA 90601, USA) subcutaneously on the ventral side of the fish just adjacent to the anterior portion of the anal fin. Injections were usually made with a $26 \frac{1}{2} \mathrm{G}$ needle, although $30 \frac{1}{2} \mathrm{G}$ needles were sometimes used for fishes that were $<25 \mathrm{~mm}$ SL. Sculpins were given 3 color dots which represented the tidepool they were from, the date of their capture and their size class. Fishes were a priori divided into 8 size classes represented by 1 of 8 colors: $\leq 25,26-30,31-35,36-40$, $41-50,51-60,61-70$, and $>70 \mathrm{~mm}$ SL. The smallest size class $(\leq 25 \mathrm{~mm}$ SL) represents those fishes that recruited within the previous month and the smallest 3 size classes represent pre-reproductive juveniles. Since these fishes tend to recruit and grow in cohorts, I chose this method over an individual marking method to facilitate marking large numbers of fishes in the field.

Consequences of timing of recruitment to growth and survivorship. I examined the consequences of variable timing in recruitment for early growth and survivorship. From data on marked individual fishes and marked cohorts of fishes, I estimated the length of time it took a new recruit of each species to attain reproductive size and the probability that a new recruit survived to reproductive size when it entered the population at varying points in the recruitment season.

Mark-recapture studies often resulted in fishes that were uniquely distinguishable by a combination of characters that included species, gender, length and the color and position of the paint mark. From these marked individuals, I was able to determine individual growth rates in $\mathrm{mm} \mathrm{mo}^{-1}$ for 384 individual fishes of 3 species. I tested whether size, species identity, and seasonal effects were important to growth using an ANCOVA (analysis of covariance) with size as the covariate. I divided the year into a winter (Oct-Mar) and a summer (Apr-Sep) season for these analyses, where the summer season brackets the period of upwelling at these northerly latitudes (Parrish et al. 1981). I then used a winter and a summer linear regression equation for each species to simulate the size trajectory for 2 to 3 y of an individual that recruited in different months during the recruitment season. From these simulations I estimated the number of months it would take for an individual to attain approximate reproductive size $(35 \mathrm{~mm}$ SL) when it recruited from May until September.

In addition to examining the growth rate of fishes that recruited at various times, I also estimated the probability of surviving to $35 \mathrm{~mm}$ SL as a function of recruiting in different months during the recruitment season. Survivorship rates for juveniles $(\leq 35 \mathrm{~mm} \mathrm{SL}$ ) were estimated from the loss of marked fishes during monthly intervals from the 9 Tatoosh Island tidepools over 3 yr I estimated survivorship 2 ways and found the results to be concordant (Pfister 1996). The survivorship estimates used here are from a log-decay function, where individuals were not tallied as dead unless they failed to ever reappear again in subsequent censuses. The remarkable site fidelity of these species resulted in repeated recaptures, sometimes as much as 3 yr later Using these mean monthly survivorship rates, I estimated the probability that an individual recruiting at $20 \mathrm{~mm}$ SL would survive to reproductive size as a function of recruiting from May through September

Physical correlates of recruitment timing and individual growth and survivorship. I tested whether an index of upwelling or mean SST $\left({ }^{\circ} \mathrm{C}\right)$ correlated with the supply of new recruits to the shore at monthly inter- 

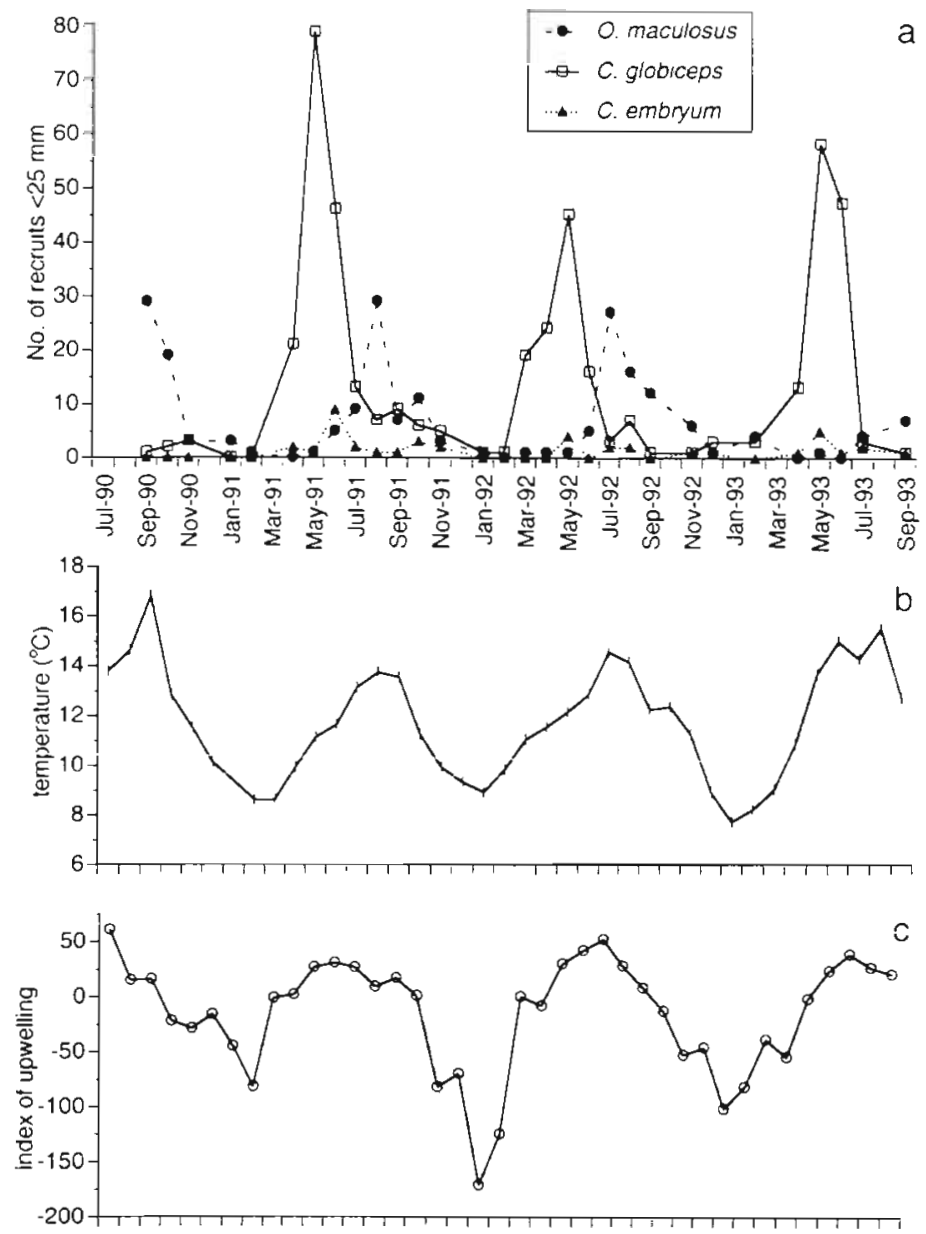

Fig. 1. Oligocottus maculosus, Clinocottus globiceps, and C embryum. (a) Pattern of appearance of new individuals $\leq 25 \mathrm{~mm}$ SL through time for 1991 through 1993 on Tatoosh Island, (b) mean monthly sea surface temperature, and (c) the monthly upwelling index $\left(\mathrm{m}^{3} \mathrm{~s}^{-1}\right.$ per $100 \mathrm{~m}$ of coastline)

vals for each species. Monthly mean values for SST $\left({ }^{\circ} \mathrm{C}\right)$ were obtained from Buoy no. 46041 at $47.4^{\circ} \mathrm{N}$ and $124.5^{\circ} \mathrm{W}, 1.0^{\circ}$ to the south and $0.23^{\circ}$ to the east of Tatoosh Island (or approximately $50 \mathrm{~km}$ to the southeast). This buoy is operated by the National Data Buoy Center (Mississippi, USA); data are logged once per second during an 8.0 min averaging period per hour and mean monthly SST values are reported in the 'Mariner's Weather Log'. Monthly intervals are the appropriate time scale to estimate correlations since this was also the frequency of sampling for fish recruitment. Upwelling indices for $48^{\circ} \mathrm{N}$ and $125^{\circ} \mathrm{W}$ were provided electronically by the National Oceanographic and Atmospheric Administration (Pacific Fisheries Environment Group, Pacific Grove, CA). Values are reported as an index in $\mathrm{m}^{3} \mathrm{~s}^{-1}$ per $100 \mathrm{~m}$ of coastline and integrate over a monthly period using surface atmospheric pressure fields to estimate wind-induced coastal upwelling

\section{RESULTS}

\section{Recruitment patterns and correlates}

Fig 1a shows the pattern of appearance of new individuals $\leq 25 \mathrm{~mm}$ SL through time for 1991 through 1993 on Tatoosh Island. Since these individuals are probably $\leq 1$ mo in age (based on individual growth data, see below), Fig 1a provides a good indication of the number of new recruits on a monthly basis. The abundance of recruits peaks in the spring/summer months, with Clinocottus globiceps generally peaking in May, C. embryum in June and Oligocottus maculosus in July and August. In all 3 years, the peak recruitment for $C$. globiceps preceded that of $O$. maculosus

Mean SST and upwelling also cycled seasonally over this 3 yr period (Fig. 1b, c, respectively). I examined whether temperature or upwelling values correlated with the number of recruits using cross correlation analyses. I specifically asked whether there were correlations among recruitment and these oceanographic events with lags or leads of up to 3 mo. In other words, were prior temperature and upwelling important to the magnitude of recruitment? Oligocottus maculosus recruitment was positively correlated with temperature at no lag and at intervals of 1 or 2 mo earlier (Fig. 2a). O. maculosus recruitment was also positively correlated with temperature the following month. This pattern is corroborated in Fig. 1a, b where peaks in SST coincide with peaks in $O$. maculosus recruitment. In contrast, Clinocottus globiceps recruitment correlated negatively with temperature at periods from 2 and 3 mo earlier (Fig. 2b). C. embryum recruitment showed no correlations with temperature (Fig. 2c).

Oligocottus maculosus recruitment was positively correlated with the upwelling index at no lag and at lags of 1, 2 and 3 mo (Fig. 3a). In contrast, upwelling indices simultaneous with and 1,2 and 3 mo later than Clinocottus globiceps recruitment correlated positively (Fig. 3b), although there was also a significant negative correlation with upwelling 3 mo earlier There were no correlations between upwelling and $C$. embryum recruitment. These correlations are consistent with the patterns seen in Fig. 1: peaks in upwelling are concurrent with both $O$. maculosus and $C$. globiceps recruitment, but tend to precede $O$. maculosus recruitment and follow peak $C$. globiceps recruitment.

One concern with doing a large number of correlative analyses is the expectation that some correlations will be significant due only to chance. I used the tem- 


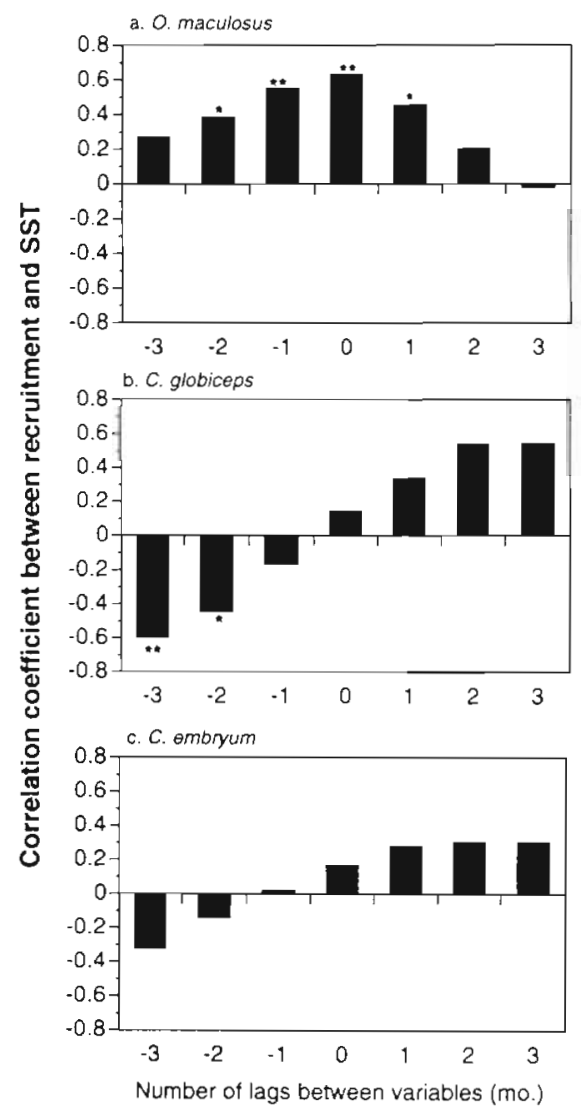

Fig. 2. (a) Oligocottus maculosus, (b) Clinocottus globiceps, and (c) C. embryum. Cross correlation coefficients between recruitment and mean sea surface temperature (SST). The correlation coefficient was estimated contemporaneously (no lag) and using temperature values obtained 1 to 3 mo before or after the recruitment estimate. Asterisks indicate statistical significance: ${ }^{\circ} p<0.05 ;{ }^{\prime} p<0.01$

perature and upwelling data for 21 correlation tests and should thus expect 1 significant result (at $p<$ 0.05) for each test purely by chance. For correlations among upwelling and number of recruits, I found 9 significant results, while correlations using temperature showed 8 significant results. Thus, in both cases, I found evidence for more significant relationships among these variables than would be expected by chance.

\section{Growth rates}

Growth rates differed significantly among species when size was used as a covariate (Table 1). Analyzing species separately indicated that size explained a significant amount of the variation for Oligocottus maculosus and Clinocottus embryum growth rates, but not for C. globiceps (Table 2). O. maculosus and $C$

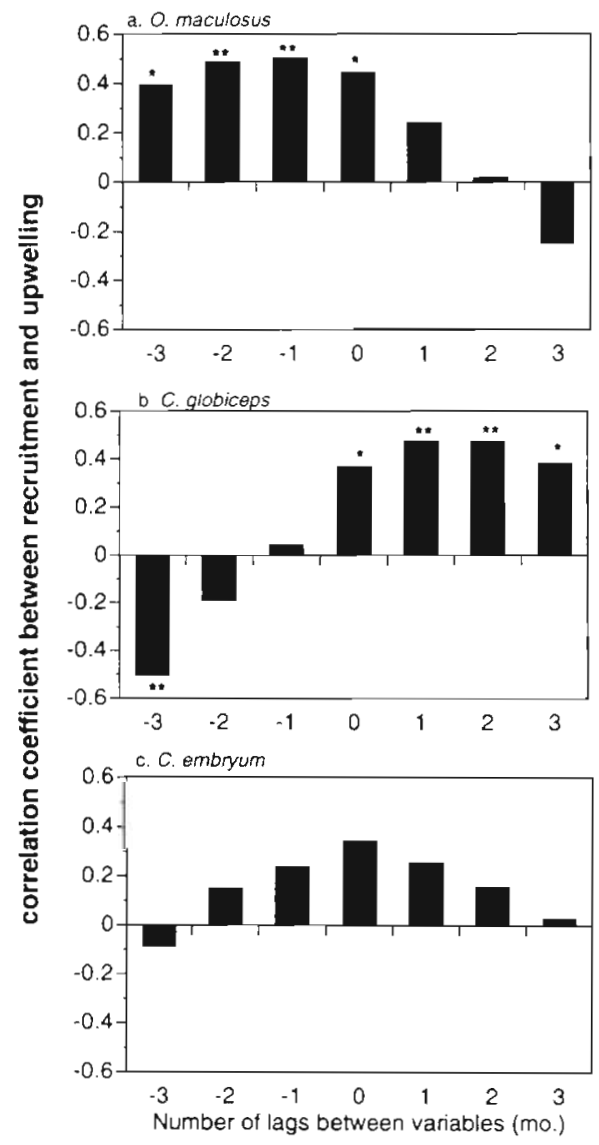

Fig. 3. (a) Oligocottus maculosus, (b) Clinocottus globiceps, and (c) C embryum. Cross correlation coefficients between recruitment and an index of upwelling. The correlation coefficient was estimated contemporaneously (no lag) and using pressure estimates obtained 1 to 3 mo before or after the recruitment estimate. Asterisks indicate statistical significance: $" p<0.05 ; \cdots p<0.01$

embryum growth rates were significantly affected by season, with summer growth rates greater than those of winter (Table 2, Fig. 4). C. globiceps growth rates might have been affected by season, although the relationship was only marginally significant (Table 2, Fig. 4). Size and season explained $57 \%$ and $40 \%$ of the total variation in growth rate for $C$. embryum and $O$. maculosus respectively (Table 2). In contrast, only $11 \%$

Table 1 ANCOVA testing whether individual growth rates differ among Oligocottus maculosus, Clinocottus globiceps and $C$. embryum using size ( $\mathrm{mm} \mathrm{SL}$ ) as a covariate

\begin{tabular}{|lrrrrc|}
\hline Source & \multicolumn{1}{c}{ SS } & df & MS & $F$ & p \\
\hline Species & 208.1 & 2 & 104.1 & 25.9 & $<0.001$ \\
Size & 206.9 & 1 & 206.9 & 51.4 & $<0.001$ \\
Error & 1528.4 & 380 & 4.0 & & \\
\hline
\end{tabular}


Table 2. Two-way ANOVAs testing the effect of size (mm SL) and season (summer vs winter) on species growth rates

\begin{tabular}{|lccrrr|}
\hline Source & SS & $\mathrm{df}$ & MS & $F$ & $\mathrm{p}$ \\
\hline Oligocottus maculosus, $\mathrm{r}^{2}=0.399$ & & & \\
Size & 81.9 & 1 & 81.9 & 33.3 & $<0.001$ \\
Season & 64.8 & 1 & 64.8 & 26.4 & $<0.001$ \\
Size $\times$ Season & 25.6 & 1 & 23.6 & 9.6 & 0.002 \\
Error & 373.4 & 152 & 2.5 & & \\
Clinocottus globiceps, $\mathrm{r}^{2}=0.105$ & & & \\
Size & 5.2 & 1 & 5.2 & 0.9 & 0.339 \\
Season & 20.1 & 1 & 20.1 & 3.5 & 0.062 \\
Size $\times$ Season & 7.2 & 1 & 7.2 & 1.3 & 0.263 \\
Error & 785.9 & 138 & 5.7 & & \\
C. embryum, $\mathrm{r}^{2}=0.567$ & & & & \\
Size & 43.9 & 1 & 43.9 & 30.1 & $<0.001$ \\
Season & 7.4 & 1 & 7.4 & 5.1 & 0.028 \\
Size $\times$ Season & 5.0 & 1 & 5.0 & 3.4 & 0.068 \\
Error & 87.6 & 60 & 1.5 & & \\
\hline
\end{tabular}

of the variability in C. globiceps growth is explained by size and season. The interaction between size and season for $O$. maculosus and to a lesser extent for $C$ embryum ( $p=0.068$ ) indicated that smaller individuals of those species respond more positively to summer growth conditions. In other words, adult growth rates benefit less during summer conditions than juvenile growth rates.

\section{Consequences of timing of recruitment to growth and survivorship}

Recruitment earlier in the season favored rapid growth and higher survivorship to reproductive size in all 3 species (Fig. 5). Using the equations for summer and winter growth in Table 3 (based on the analyses in Tables $1 \& 2$ ), the number of months it took for individuals of each species to reach reproductive size increased as the summer progressed. For example, an Oligocottus maculosus that recruited in a. O. maculosus

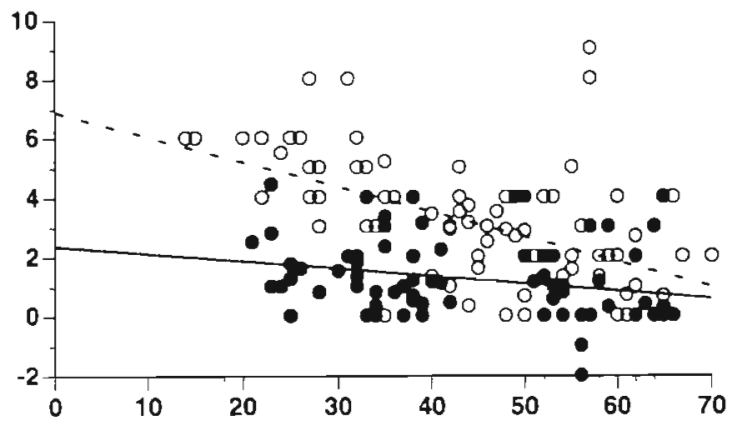

b. C. glabiceps

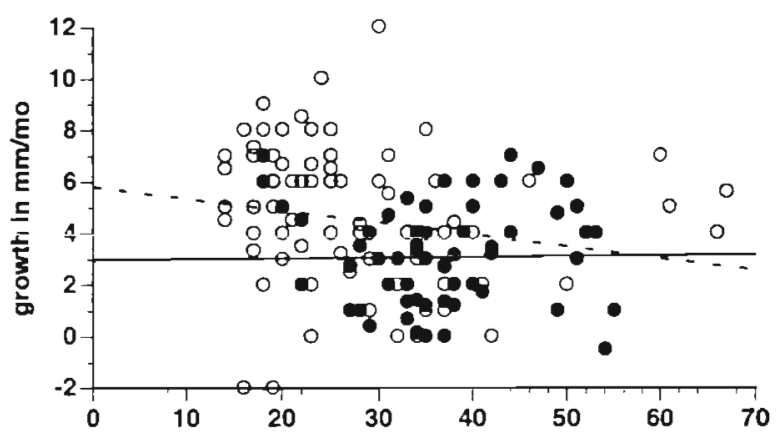

c. C. embryum

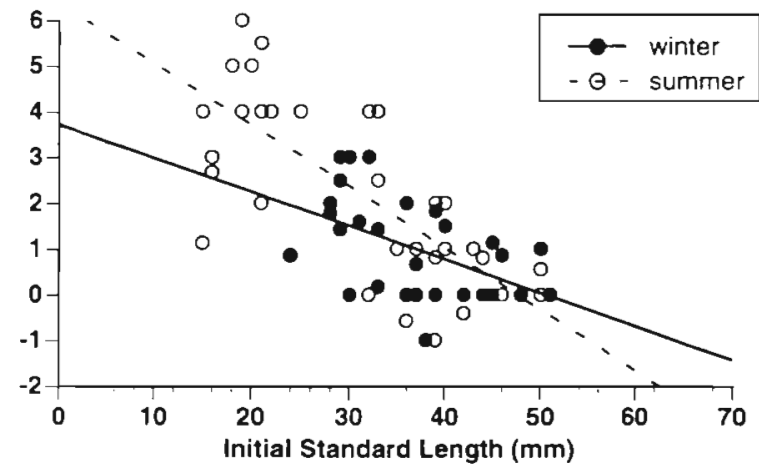

Fig. 4. (a) Oligocottus maculosus, (b) Clinocottus globiceps, and (c) C. embryum. Individual growth rates as a function of initial standard length in both summer (O) and winter (-) months. (- - -) Best linear fit to summer growth rates; $(-)$ best linear fit to winter growth rates

Table 3. Linear regressions of growth rate $\left(G\right.$, in $\mathrm{mm} \mathrm{mo}^{-1}$ ) as related to size (in $\mathrm{mm} \mathrm{SL}$ ) in both the summer season (Apr-Sep) and the winter season (Oct-Mar) for each of the 3 species

\begin{tabular}{|c|c|c|}
\hline Species & Summer & Winter \\
\hline Oligocottus maculosus & $\begin{array}{c}G=6.898-0.084(\text { size }) \\
n=81\end{array}$ & $\begin{array}{c}G=2.372-0.025(\text { size }) \\
\mathrm{n}=75\end{array}$ \\
\hline Clinocottus globiceps & $\begin{array}{c}G=6.759-0.043(\text { size }) \\
n=82\end{array}$ & $\begin{array}{c}G=2.955-0.003 \text { (size) } \\
\mathrm{n}=60\end{array}$ \\
\hline C. embryum & $\begin{array}{c}G=6.413-0.134(\text { size }) \\
n=37\end{array}$ & $\begin{array}{c}G=3.409-0.066(\text { size }) \\
n=27\end{array}$ \\
\hline
\end{tabular}




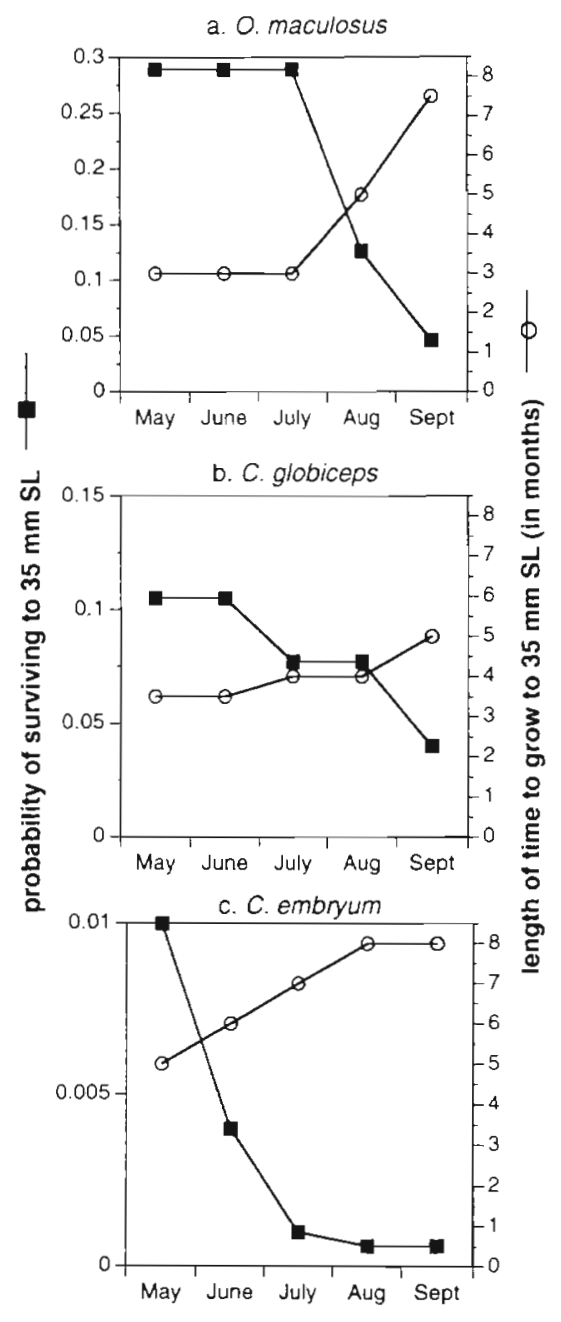

Fig. 5. (a) Oligocottus maculosus, (b) Clinocottus globiceps, and (c) C. embryum. Probability that an individual recruiting at $20 \mathrm{~mm} \mathrm{SL}$ survives to $35 \mathrm{~mm}$ SL (approximate size of first reproduction), and length of time it takes an individual to attain reproductive size as a function of what month it recruits in the spring and summer. Survivorship probabilities are based on Pfister (1996). The times required to grow to reproductive size are based on the linear regression equations in Table 3

June would be $35 \mathrm{~mm}$ SL by September, whereas one that recruited in September will not reach that size until April. Since $O$. maculosus can reproduce at $35 \mathrm{~mm}$ SL and reproduction occurs in the winter months (author's pers. obs.), then $O$. maculosus that recruit in August and September are unlikely to reproduce in their first year (Fig. 5a). In contrast, Clinocottus globiceps recruits are likely to be $35 \mathrm{~mm}$ SL by their first winter, unless they recruit in September, an infrequent event (Fig. 1a).

Because individuals of all species take longer to reach reproductive size when recruitment occurs later in the season, their survivorship to reproductive size also declines. For Oligocottus maculosus, recruits in September experience a $87.5 \%$ decline in survivorship to reproductive size compared with individuals that arrive in June. Again, seasonality has a less drastic affect on Clinocottus globiceps: recruits in September experience a $61.9 \%$ decline in survivorship to reproductive size compared with individuals that arrive in June. The probability of surviving to reproductive size peaks in May for C. embryum and declines continuously thereafter.

From Fig. 5, one can bracket roughly the best months for future performance (including survivorship and growth) of recruits of each species. Oligocottus maculosus recruits do best from May to July, Clinocottus globiceps in May and June and C. embryum in May only.

\section{DISCUSSION}

\section{Consequences of recruitment timing}

The timing of peak recruitment can differ between years (Fig 1a), both affecting the probability that an individual survives to reproduce and determining whether an individual will realize sufficient growth to reproduce in its first winter (Fig. 5). For all species, recruitment earlier in the summer appears to be most beneficial when performance criteria of early growth and survivorship are used. Individuals that recruit later in the summer pay survivorship and growth costs, including a delay in first reproduction of 1 yr. However, one species (Oligocottus maculosus) rarely recruits early in the summer, generally not appearing until July or August. Although July recruits would suffer no growth or survivorship costs, recruits in August or later would. This 'mismatch' between what appears to be best for individuals of $O$. maculosus and what I observe in the field is difficult to interpret, but may be linked to trade-offs in timing with other phases of the life cycle such as adult breeding and larval release. Similarly, Booth (1995) showed that although recruitment and enhanced survivorship and growth coincided in the late summer for an Hawaiian coral reef damselfish. late-settling fish were smaller in the winter due to minimal winter growth rates and were more vulnerable to predation.

The variability in arrival of sculpin recruits to the shore may be driven, in part, by variation in oceanographic factors such as upwelling and SST. Maximum SST coincided with Oligocottus maculosus recruitment (Fig. 2a), while peaks in upwelling coincided with recruitment in $O$. maculosus and Clinocottus globiceps. Both temperature and upwelling can be characterized by high interannual variation, with the timing of the 
peak value varying among years. For example, seasonal maximum values for mean monthly SST occurred in July in 1992, during August in 1991 and 1993, and during September in 1990 (Fig. 1b). Similarly, the strength and duration of upwelling can vary among years, although Fig. 1c shows relatively constant peak upwelling from 1990 to 1993. Previous studies in temperate environments have also shown a strong correlation between large-scale oceanographic events and recruitment (Parrish et al. 1981, Shanks 1983, Sissenwine 1984, Roughgarden et al. 1988). Here, I have shown that variation in these oceanographic events can also affect strongly the early life history events of newly recruited individuals.

Recruitment in each species correlated differently with SST and upwelling, with maximum upwelling often preceding Oligocottus maculosus recruitment and following Clinocottus globiceps recruitment. The interspecific differences in contelations with oceanographic events and recruitment suggest either: (1) physiologically, these fish species respond differently to upwelling events or temperature; or (2) these species are distributed differently (spatially or temporally) in the water column as larvae and encounter oceanographic phenomena distinctly. Currently, these hypotheses are indistinguishable, since so little is known about the dispersal and distribution patterns of these larval fishes.

Although interannual variability can characterize both oceanographic events and correlated recruitment success, the causal factors driving interannual differences in recruitment of these fishes remains unknown. A multitude of causal factors, alone or in concert, may be important, including how oceanographic events might affect the variability in the time of spawning (e.g. Secor \& Houde 1995), differences in larval growth and survivorship (e.g. Kneib 1993), and variability in larval transport (e.g. Shanks 1983).

Clearly, events in the early life history and juvenile stages of an organism have the potential to influence life history strategies (e.g. Stearns 1976) and the longterm population dynamics of a species (e.g. Lewontin 1965). Here, I demonstrate that oceanographic factors, including seasonality, via their effect on the timing of recruitment, influence the early demography of intertidal sculpins. Previously, I showed that competitive interactions among fishes also affect growth and emigration rates of juveniles (Pfister 1995). We are increasingly understanding more about the juvenile stages of marine fishes, including how growth and survivorship are influenced by conspecifics (e.g. Kneib 1987, Jones 1988, Forrester 1990, Booth 1995), predators (Wright et al. 1993), and physical variables such as temperature (Rutherford \& Houde 1995) and tidal cycles (Kneib 1993)

\section{Temporal variation in ecological models}

Variability in the temporal dynamics of organism abundance has been incorporated into models that predict species co-occurrence and persistence (Chesson 1983, Schmida \& Ellner 1984, Warner \& Chesson 1985, Chesson \& Huntley 1988). Examination of many published recruitment studies indicate that interannual recruitment variation, assumed to be important in the above models, is widespread in marine taxa (e.g. Hjort 1914, Loosanoff 1946, Thorson 1950, Coe 1956 , Denley \& Underwood 1979, Sale et al. 1984, Caffey 1985, Connell 1985, Shulman 1985, Raimondi 1990. Doherty 1991, Pfister 1996). Temporal variation within a season has also been demonstrated (Loosanoff 1946 , Yoshioka 1982, Caffey 1985, Gaines \& Roughgarden 1985, Raimondi 1990, Doherty 1991, Bingham 1992, Kneib 1993).

Whether this within-season variation affects population trajectories or species interactions depends also upon the nature of post-recruitment processes. I have demonstrated here that fishes that recruit earlier maximize the time of growth during the more agreeable summer conditions, reaching reproductive size in their first breeding season, and the extent of this response varies among species. However, these effects may be minor compared with events that affect benthic adult performance in tidepools (Pfister 1996). Using sizestructured models of population growth in these intertidal sculpins, I found that variability in recruitment events was not transmitted reliably to the adult population. Instead, natural variation in adult survivorship can affect population size to a greater extent than recruitment variability, and population growth can be most sensitive to survivorship in the adult stages. Other studies of marine fish demography also suggest that events during adult stages can strongly affect population dynamics. For example, a number of studies have demonstrated interspecific competitive interactions among marine fishes (e.g. Hixon 1980, Sweatman 1985, Schmitt \& Holbrook 1986, 1990, Robertson 1996), including the fish species discussed in this study (Pfister 1995).

Although the results reported here indicate oceanographic correlates of early demographic events in marine fishes, these results do not imply that intertidal sculpin population dynamics are driven solely by these early events. The extent to which pelagic and recruitment events versus subsequent processes during later stages influence population dynamics will depend upon whether density dependent processes occur, the lifespan of the species, and the extent to which recruitment success and survivorship covary (e.g. Benton \& Grant 1996). In order to integrate pelagic and benthic events in the life history of marine organisms, we need 
to understand not only what processes are important in different life history stages, but also the net demographic effects these processes have

Acknowledgements. I thank J. T Wootton, P. Nitschke, R. T Pane, W. P. Sousa and 2 anonymous reviewers for comments on the manuscript. I am grateful to the Pacific Fisherics Environment Group of NOAA for the upwelling data. All other data collection was funded by the Lerner Gray Fund for Marine Research, Sigma Xi Grants-in-Aid, and NSF grant no. OCE 91.15760 to R. T Paine. The Miller Foundation for Rasic Research in Science and the Andrew W. Mellon Foundiation provided support during the preparation of the manuscript. The Makah Tribal Nation permitted access to the study area and Big Salmon and Eagle Air assured safe transport.

\section{LITERATURE CITED}

Babcock RC, Bull GD, Harrison PL, Heyward AJ, Oliver JK, Wallace CC. Willis BL (1986) Synchronous spawnings of 105 scleractinian coral species on the Great Barrier Reef. Mar Biol 90:379-394

Benton TG, Grant A (1996) How to keep fit in the real world: elasticity analyses and selection pressures on life histories in a variable environment. Am Nat 147:115-139

Bingham BL (1992) Life histories in an epifaunal community: coupling of adult and larval processes. Ecology 73: $2244-2259$

Booth DJ (1995) Juvenile groups in a coral-reef damselfish: density-dependent effects on individual fitness and population demography. Ecology 76:91-106

Caffey HM (1985) Spatial and temporal variation in settlement and recruitment of intertidal barnacles. Ecol Monogr $55: 313-332$

Chesson PL (1983) Coexistence of competitors in a stochastic environment: the storage effect. Lect Notes Biomath 52 $188-198$

Chesson PL, Huntly N (1988) Community consequences of life-history traıts in a variable environment. Annls Zool Fenn 25:5-16

Coe WR (1956) Fluctuations in populations of littoral marine invertebrates. J Mar Res 15:212-232

Connell $\mathrm{J}$ (1985) The consequences of variation in initial settlement versus postsettlement mortality in rocky intertidal communities. J Exp Mar Biol Ecol 93:11-45

Denley EJ, Underwood AJ (1979) Experiments on factors influencing settlement, survival, and growth of two species of barnacles in New South Wales. J Exp Mar Biol Ecol 36:269-293

Doherty PJ (1991) Spatial and temporal patterns in recruitmont. In: Sale PF (ed) The ecology of fishes on coral reefs. Academic Press, San Diego, p 261-293

Doherty PT, Fowler T (1994) An empirical test of recruitment limitation in a coral reef fish. Science 263:935-939

Forrester GE (1990) Factors influencing the juvenile demography of a coral reef fish. Ecology 71:1666-1681

Gaines S, Roughgarden J (1985) Larval settlement rate: a leading determinant of structure in an ecological community of the marine intertidal zone. Proc Natl Acad Sci USA $82: 3707-3711$

Green JM (1971) High tide movements and homing behavior of the tidepool sculpin Oligocottus maculosus. J Fish Res Bd Can 28:383-389

Green JM (1973) Evidence for homing in the mosshead sculpin (Clinocottus globiceps). J Fish Res Bd Can 30:129-130
Grossman GD (1982) Dynamics and organization of a rocky intertidal fish assemblage: the persistence and resilience of taxocene structure. Am Nat 119:611-637

Hart JL (1973) Pacific fishes of Canada. Bull Fish Res Bd Can 180

Hixon MA (1980) Competitive interactions between California reef fishes of the genus Embiotoca. Ecology 61: 918-931

Hjort $J$ (1914) Fluctuations in the great fisheries of northern Europe. Rapp PV Réun Con Int Explor Mer 20:1-228

Johannes RE (1978) Reproductive strategies of coastal marine fishes in the tropics. Environ Biol Fish 3:65-84

Jones GP (1988) Experimental evaluation of the effects of habitat structure and competitive interactions on juveniles of two coral reef fishes. J Exp Mar Biol Ecol 123.115-126

Jones GP (1990) The importance of recruitment to the dynamics of a coral reef fish population. Ecology 71:1691-1698

Kneib RT (1986) Size-specific patterns in the reproductive cycle of the killfish Fundulus heteroclitus (Pisces: Funulidae) from Sapelo Island, Georgia USA. Copeia 1986: $342-351$

Kneib RT (1987) Predation risk and use of intertidal habitats by young fishes and shrimp. Ecology 68:379-386

Kneıb RT (1993) Growth and mortality in successive cohorts of fish larvae within an estuarine nursery. Mar Ecol Prog Ser 94:115-127

Korringa P (1947) Relationship between the moon and pernodicity in the reeding of marine anmals. Ecol Monogr 17 . $347-381$

Lewontin RC (1965) Selection for colonizing ability. In: Baker HG, Stebbins GL (eds) The genetics of colonizing ability. Academic Press, New York, p 77-92

Loosanoff VL (1964) Variations in time and intensity of settling in the starfish, Asterias forbes, in Lony Island Sound during a twenty-five year period. Biol Bull 126:423-439

Marliave JB (1986) Lack of planktonic dispersal of rocky intertidal fish larvae. Trans Am Fish Soc 115:149-154

McFarland WN, Brothers EB, Ogden JC, Shulman MJ, Bermingham EL, Kotchian-Prentiss NM (1985) Recruitment patterns in young french grunts, Haemulon flavolineatum (family Haemulidae) at St. Croix, U.S.V.I. Fish Bull US 83:413-426

Morgan SG, Christy JH (1995) Adaptive significance of the timing of larval release by crabs. Am Nat 145:457-479

Parrish RH, Nelson CS, Bakun A (1981) Transport mechanisms and reproductive success of fishes in the Californ.a Current. Biol Oceanogr 1:175-203

Pfister CA (1993) The dynamics of fishes in intertidal pools. Dissertation, University of Washington, Seattle

Pfister CA (1995) Estimating competition coefficlents from census data: a test with field manipulations of tidepool fishes. Am Nat 146:271-291

Pfister CA (1996) The role and importance of recruitment variability to a guild of tide pool fishes. Ecology 77 : 1928-1941

Raimondi PT (1990) Patterns, mechanisms, consequences of variability in settlement and recruitment of an intertudal barnacle. Ecol Monogr 60:283-309

Richkus WA (1973) A quantitative study of intertidepool movement of the wooly sculpin Clinocottus analis. Mar Biol 49:277-284

Robertson DR (1996) Interspecific competition controls abundance and habitat use of territorial Caribbean damselfishes. Ecology 77:885-889

Robertson DR, Peterson CW, Brawn JD (1990) Lunar reproductive cycles of benthic-brooding reef fishes: reflections of larval biology or adult biology? Ecol Monogr 60:311-329 
Roughgarden J, Gaines S, Possingham H (1988) Recruitment dynamics in complex life cycles. Science 241:1460-1466

Rutheriord ES, Houde ED (1995) The influence of temperature on cohort-specific growth, survival, and recruitment of striped bass, Morone saxatilis, larvae in Chesapeake Bay, US Natl Mar Fish Serv Fish Bull 93:315-332

Sale PF (1977) Maintenance of high diversity in coral reef fish communities. Am Nat 111:337-359

Sale PF, Doherty PJ, Eckert G.J, Douglas WA, Ferrell DJ (1984) Large scale spatial and temporal variation in recruitment to fish populations on coral reefs. Oecologia 64 $191-198$

Schmida A, ElIner S (1984) Coexistence of plant species with similar niches. Vegetatio 58:29-55

Schmitt RJ, Holbrook SJ (1986) Seasonally fluctuating resources and temporal variability of interspecific competition. Oecologia $69: 1-11$

Schmitt RJ, Holbrook SJ (1990) Population responses of surfperch released from competition. Ecology 71:1653-1665

Secor DH, Houde ED (1995) Temperature effects on the timing of Striped Bass egg production, larval viability, and recruitment potential in the Patuxent River (Chesapeake Bay). Estuaries 18:527-544

Shanks AL (1983) Surface slicks associated with tidolly forces internal waves may transport pelagic larvae of benthic invertebrates and fishes shoreward. Mar Ecol Prog Ser 13: $311-315$

Shulman MJ (1985) Coral reet $t i s h$ assemblages: intra- and interspecific competition for shelter sites. Environ Biol Fish 13:81-92

Shulman MJ, Ogden JC, Ebersole JP, MCFarland WN, Miller SL. Wolf NG (1983) Priority effects in the recruitment of uvenile coral reef fishes. Ecology 64:1508-1513

Sissenwine MP (1984) Why do fish populations vary? In: May RM (ed) Exploitation of marine communities. SpringerVerlag, Berlin, p 59-94

Stearns SC (1976) Life-history tactics: a review of the ideas. $Q$ Rev Biol 51:3-47

This article was presented by K. Sherman (Senior Editorlal Advisor), Narragansett, Rhode Island, USA
Strub PT, Allen JS, Huyer A, Smith RL (1987) Large-scale structure of the spring transition in the coastal ocean of western North America. J Geophys Res 92(C2):1527-1544

Strub PT, James C (1988) Atmospheric conditions during the spring and fall transitions in the coastal ocean off western United States. J Geophys Res 93(C12):15561-15584

Sweatman HP (1985) The influence of adults of some coral reef fishes on larval recruitment. Ecol Monogr 55:469-485

Thorson G (1950) Reproductive and larval ecology of marine bottom invertebrates. Biol Rev 25:1-45

Victor BJ (1983) Recruitment and population dynamics of a coral reef fish. Science 219:419-420

Victor BJ (1986) Larval settlement and juvenile mortality in a recruitment-limited coral reet fish population. Ecol Monogr 56:145-160

Waples RS (1987) A multispecies approach to the analysis of gene flow in marine shore fishes. Evolution 41:385-400

Warner RR, Chesson PL (1985) Coexistence mediated by recrutment fluctuations: a field guide to the storage effect. Am Nat 125:769-787

Washington BB, Moser HG, Laroche WA, Richards WJ (1984) Scorpaeniformes: development. Ontogeny and systematIcs of fishes. Speciai Pubilcation no. 1. Anerican Suciety of Ichthyologists and Herpetologists

Wright RA, Crowder LB, Martin TH (1993) The effects of predation on the survival and size-distribution of estuarine fishes: an experimental approach. Environ Biol Fish 36: 291-300

Yoshioka PM (1982) Role of planktonic and benthic factors in the population dynamics of the bryozoan Membranipora membranacea. Ecology 63:457-468

Yoshiyama RM, Gaylord KB, Philippart MT, Moore TR, Jordan JR, Coon CC, Schalk LL, Valpey CJ, Tosques I (1992) Homing behavior and site fidelity in intertidal sculpins (Pisces: Cottidae). J Exp Mar Biol Ecol 160:115-130

Yoshiyama RM, Sassaman C (1987) Geographical patterns of allozymic variation in three species of intertidal sculpins. Environ Biol Fish 20:203-218

Manuscript first received: June 19, 1996

Revised version accepted: April 8, 1997 